\title{
PEMANFAATAN MEDIA SOSIAL PADA PILKADA 2018 \\ DI KABUPATEN DONGGALA
}

\author{
Anisa Safanet \\ Program Studi Ilmu Komunikasi FISIP Universitas Tadulako \\ Email:anisasafanet@gmail.com
}

\begin{abstract}
ABSTRAK
Tujuan penelitian ini untuk mendeskripsikan persepsi pemula dengan dasar penelitian survey dan menggunakan metode kuantitatif. Populasi dalam penelitian ini berjumlah 248 orang dan menentukan sampel sebesar 71 orang dengan teknik sampling random sederhana. Hasil penelitian menunjukkan bahwa: 1). terdapat perhatian responden terhadap berita pilkada melalui facebook (58 responden); 2). tidak terdapat kesesuaian informasi dan harapan pada media sosial facebook (42 responden); 3). informasi melalui facebook tentang pilkada bukan sesuatu kebutuhan (34 responden); 4). sistem nilai penting dalam media sosial facebook dan tidak bertentangan (53 responden); 5). Terdapat kesesuaian dengan kepribadian, serta terdapat perbedaan persepsi diantara pemilih pemula dalam menentukan pilihan ( 57 responden).
\end{abstract}

\section{Kata Kunci: Persepsi; Media Sosial; Pemilih Pemula; Pilkada}

\section{Submisission: 26 April 2021}

\section{Pendahuluan}

Sesuai dengan meningkatnya kebutuhan manusia untuk berkomunikasi, maka banyak pula ahli yang memunculkan berbagai inovasi teknologi komunikasi dimana pada zaman ini sangat berperan dalam aktivitas keseharian bersosial di masyarakat. Sangatlah memungkinkan masyarakat untuk bisa mengakses informasi apa saja yang mereka butuhkan. Perkembangan teknologi komunikasi ini sangat pesat dan memberikan dampak yang signifikan di berbagai bidang seperti politik, pendidikan, ekonomi, dan bidang lainnya. Inovasi-inovasi yang muncul ini memiliki kontribusi dalam menciptakan keberagaman media pada era teknologi, khususnya media sosial yang semakin mudah diakses dan dilakukan dimana saja.

Dalam mengakses media sosial hanya bermodalkan jaringan internet dan ditunjang oleh perangkat seperti ponsel, tablet, laptop, dan komputer. Terdapat ratusan saluran media sosial yang beroperasi di seluruh dunia saat ini, dengan Facebook sebagai media sosial berbentuk layanan jejaring sosial yang paling banyak digunakan (http://wearesocial.com).

Layanan jejaring sosial merupakan platform atau situs yang bertujuan memfasilitasi hubungan sosial diantara orang-orang yang memiliki ketertarikan, aktivitas, latar belakang, maupun hubungan dunia nyata yang sama. Perkembangan teknologi juga ditandai dengan lahirnya aktivitas berita online seperti 
detik.com dan lain termasuk media sosial berupa facebook. Hal ini memungkinkan khalayak dapt mengakses dengan cepat dan mudah tanpa memerlukan biaya besar. Setiap individu memiliki peluang yang sama untuk dapat mengakses informasi tersebut. Hal ini menunjukkan bahwa dengan mudahnya mengakses facebook berarti informasi yang didapatkan juga dengan mudah dibagi dan disebar secara meluas. Sejalan dengan hal tersebut, sebagaimana dikemukakan Lalolo K.P., \& Zainal (2018) menjelaskan bahwa jejaring sosial merupakan bagian dari sosial media. Walaupun keduanya memiliki kemiripan, tetapi secara konseptual keduanya adalah berbeda. Dalam konsep jaringan, media sosial merupakan alat yang memfasilitasi proses berjejaring.

Dengan kekuatan media sosial ini, politisi, warga dan wartawan semakin mengadopsi media sosial baru seperti Facebook untuk mendukung terwujudnya harapan mereka. Sejalan dengan hak tersebut, sebagaimana Habermas (2006) yang menyatakan, bahwa para pemangku kepentingan menggunakan ruang publik untuk politik, kampanye, menyebarkan atau mengambil informasi, atau berkontribusi terhadap perdebatan rasional - kritis. Dengan demikian dapat ditegaskan bahwa media sosial merupakan salah satu alat yang paling penting sebagai kunci untuk mempengaruhi masyarakat.

Dalam beberapa studi yang berbeda dari kebiasaan warga dalam pemungutan suara, sejak investigasi Lazarsfeld klasik pada 1940-an, hasil menunjukkan bahwa keputusan tidak biasanya didasarkan pada satu langkah komunikasi. Lebih penting adalah dua langkah komunikasi, yang berarti percakapan dengan pemimpin opini, kolega, teman dan kenalan yang dapat mengkonsolidasikan baik atau melemahkan pendapat pemilih (Social media - The New Power Of Political Influence Version 1.O AriMatti Auvinen Centre for European Studies).

Saat ini, hampir semua orang menggunakan media sosial, bahkan satu orang bisa mempunyai banyak akun untuk mengakses berbagai situs media sosial, khususnya pemilih pemula. Pemilih pemula di Indonesia pada umumnya masih Pelajar tingkat SLTA dan Mahasiswa, mereka dianggap lebih melek teknologi dan paling rentan terhadap pengaruh yang ada di media sosial, seperti pada jejaring sosial Facebook. Akses pada internet makin luas, media sosial mudah diakses, membuat para pemilih pemula sangat tertarik pada perkembangan- perkembangan terkait partai politik, politisi, dan prosesproses politik. Pihak-pihak yang bertujuan untuk berkampanye pun semakin tertarik pada pemilih pemula.

Kelahiran teknologi yang disebut dengan media baru, selain dapat digunakan pada hal yang positif juga dapat menimbulkan dampak yang negative seperti yang disampaikan Bungin (2014:366) bergugurannya media cetak ketika penerbitan edisi online di dunia maya dikembangkan. Selain itu penggunaan handphone menjadi alat utama perilaku menyimpang, bahkan mereka sanggup mengkoneksikan jaringana telpon, internet, atm, dan kode rahasia bank (pin) untuk membobol bank tersebut. Lahirnya dampak positif atau negatifnya sangat tergantung 
pada pengguna handphone tersebut. Berhubungan dengan informasi terntang pilkada tentunya salah satu bagian dari dampak positif.

Berdasarkan Undang-Undang No. 12 Tahun 2008 dalam pasal 59 ayat (1) menyebutkan, peserta pemilihan kepala daerah dan wakil kepala daerah adalah pasangan calon yang diusulkan oleh partai politik atau gabungan partai politik dan pasangan calon perseorangan yang didukung oleh sejumlah orang. Pemilihan kepala daerah dan wakil kepala daerah Donggala tahun 2018 merupakan pemilihan umum di Kabupaten Donggala, untuk memilih Bupati dan Wakil Bupati periode 2018-2023. Hal Ini merupakan pemilihan bupati secara langsung ketiga setelah Pilkada Donggala 2008 dan Pilkada Donggala 2013.

Pemilihan Kepala daerah dan wakil kepala daerah Kabupaten Donggala diikuti oleh empat pasangan calon dan satu diantaranya dari calon perseorangan. Keempat pasangan calon tersebut adalah Anita Bugiswati Noerdin dan Abdul Rahman; Kasman Lasa dan Moh.Yasin; Vera Elena Laruni dan Taufik M Burhan dan Idham Palaguna dan Mohammad Yasin M Lataka (calon Perseorangan). Keempat pasangan calon tersebut berupaya menggunakan berbagai media untuk memenangkan paslon masing-masing.

Pilkada tidak dapat lepas dari pengaruh media sosial hal ini disebabkan karena orientasi popularitas sebagai pendorong utama, sebagai asumsi semakin popular pasangan calon semakin besar kemungkinan memenangkan pertarungan politik, Subiakto dan Ida
(2012). Dengan demikian, penggunaan media sosial tidak terelakan guna meraih suara khalayak khususnya pemilih pemula. Melalui pemilihan ini sangat dipastikan bahwa partai pengusung berupaya semaksimal mungkin mempengaruhi dan menarik simpatik pemilih di wilayah itu, termasuk pemilih pemulai melalui media sosial. Berita yang ditampilkan melalui media social dinilai dapat mempengaruhi pilihan calon pemilih, khususnya pemilih pemula pada sosok figur yang terlibat dalam pemilihan kepala daerah (pilkada) khususnya di Kabupaten Donggala.

Hadirnya teknologi modern berupa penemuan hanphone dan tersedianya internet dianggap sangat tepat dan sesuai dengan karakter melenial sebagai gaya hidup yang oleh media sosial dianggap sebagai sasaran guna merebut suara pemilih pemula. Dengan demikian, peran media sosial yang digunakan oleh berbagai kepentingan partai politik dalam memenangkan pasangan calon dan meraih suara khususnya pada pemilih pemula, maka penelitian ini diarahkan pada persepsi secara mendalam mengenai hubungan antara isi pesan media dengan persepsi apa yang dapat ditimbulkan dari pesan media tersebut.

Persepsi tidak hanya tergantung pada sifat-sifat rangsangan fisik, tapi juga pada pengalaman dan sikap dari individu. Pengalaman dapat diperoleh dari semua perbuatannya di masa lampau atau dapat pula dipelajari, sebab dengan belajar seseorang akan dapat memperoleh pengalaman. Hasil dari pengalaman yang berbeda-beda akan membentuk suatu pandangan yang berbeda sehingga menciptakan 
proses pengamatan dalam perilaku yang berbeda pula. Persepsi meliputi pengindraan melalui alat indera kita dan memiliki andil bagi keberlangsungan sebuah komunikasi. Persepsi setiap individu, dalam melihat sebuah objek tentu akan berbeda, hal ini dipengaruhi oleh faktor personal dan situasional. Oleh karena itu, dalam mempersepsi manfaat media sosial facebook tentunya akan berbeda antara pemilih pemula satu dengan lainnya. Sebab dipengaruhi oleh personal individu yang bersangkutan dan faktor situasional, dimana individu tersebut berada. Dengan demikian, terbentuknya persepsi terhadap suatu objek pada lingkungannya didasarkan pada stimulus yang sedang dihadapinya.

\section{Tinjauan Pustaka Media Baru}

Marshall McLuhan merupakan sosok yang memberikan gagasan mengenai hadirnya media baru. McLuhan mencetuskan beberapa gagasan cerdas mengenai perbedaan antara bentuk-bentuk media (J. Severin \& W. Tankard. 2011: 459). Diawali dengan mesin cetak, inovasi teknologi semakin berkembang dan memunculkan lebih banyak jenis media, serta melibatkan lebih banyak khalayak. Media baru merupakan era yang ditandai dengan apa yang disebut konvergensi media. Alat untuk mengakses dan segala inovasi dari bentuk-bentuk media baru memungkinan pengguna untuk membuat media nya sendiri.

Sejalan dengan hal tersebut John Vivian (Nasrullah, 2016:13) menjelaskan bahwa keberadaan media baru seperti internet bias melampaui pola penyebaran pesan media tradisional, sifat internet yang bias berinteraksi mengaburkan batas geografis, kapasitas interaksi dan yang terpenting bisa dilakukan secara real time. Hal ini menunjukkan bahwa pada media baru khalayak tidak sekedar ditempatkan sebagai objek yang menjadi sasaran dari pesan. Khalayak dan perubahan teknologi media, serta pemaknaan terhada medium telah memperbaharui peran khalayak untuk menjadi lebih interaktif terhadap pesan itu (Nasrullah, 2016:14). Dengan demikian, menunjukkan bahwa hadirnya media sosial sebagai wujud dari perkembangan teknologi telah membuka ruang yang selama ini tertutup menyebabkan semua kalangan dengan mudah mengakses informasi melalui situs sesuai dengan kebutuhan.

Menurut Mandiberg (2012: 1) teknologi pada masa ini telah menciptakan berbagai jenis media: message boards, audience-driven review sites, blogs and comment systems, photo and video-sharing websites, social networks, social news site, dan microblogging platforms. Dapat disimpulkan, media baru meliputi alat komunikasi jarak jauh dan media online. Walaupun media pada era media pertama tidak sepenuhnya ditinggalkan, masyarakat sekarang lebih banyak yang memilih inovasi-inovasi yang hadir setelah era media kedua atau media baru pada saat ini.

Terdapat perbedaan antara dua masa yang berbeda yaitu era media pertama dan era media kedua. Perbedaan tersebut dapat ditandai antara lain: 1). era media pertama 
ditandai dengan tersentralnya informasi dari satu sumber kebanyak khalayak; 2). pada era media kedua informasi tersebar dari banyak sumber ke banyak khalayak; 3). pada era pertama komunikasi terjadi pada satu arah, sedangkan pada era kedua komunikasi terjadi secara timbal balik; 4). pada era media pertama peluang untuk menguasai media lebih terbuka, sementara pada era media kedua penguasaan media lebih tertutup dan bebasnya control terhadap sumber media; 5). pada era media pertama, media digunakan sebagai instrument yang melanggengkan strata dan ketidaksetaraan kelas sosial, sedangkan pada era media kedua, media memfasilitasi setiap khalayak; 6). pada media pertama, terfragmentasinya khalayak dan dianggap sebagai massa, sementara pada era media kedua khalayak bisa terlihat sesuai karakternya tanpa meninggalkan keragaman identitas masing- masing; dan 7). pada era media pertama media dianggap dapat menjadi alat untuk memengaruhi kesadaran, sedangkan pada era media kedua, media melibatkan pengalaman khalayak baik secara ruang maupun waktu.

Dari tujuh poin perbedaan antara era media pertama dan era media kedua, menunjukkan bahwa pada era media kedua lebih bersifat terbuka, dapat melakukan kontrol terhadap sumber dan tanpa meninggalkan keragaman identitas masing- masing. Penekanan era media baru seperti yang dikemukakan oleh Meyrowitz dalam (Nasrullah, 2016:15), bahwa lingkungan media baru atau dikenal dengan Cyberspace telah membawa tawaran pemikiran baru terhadap riset media yang tidak hanya berfokus pada pesan semata tetapi mulai melibatkan teknologi komunikasi itu sendiri yang secara langsung maupun tidak memberikan fakta bahwa perangkat komunikasi berteknologi itu merupakan salah satu bentuk atau tipe dari lingkungan sosial.

Dari aspek perangkat media, era media baru ditandai dengan apa yang disebut konvergensi media. Secara struktural, konvergensi media berarti integrasi dari tiga aspek, yaitu telekomunikasi, data komunikasi, dan komunikasi massa dalam satu medium, Jan van Dijk dalam Nasrullah (2016). Sejalan dengan hal tersebut, Gibson 1984, memperkenalkan istilah cyberspace dalam menjelaskan bahwa ada tempat dimana ia tidak nyata tapi keberadaannya dapat dirasakan bahkan menjadi kenyataan dalam benak. Lebih lanjut, Gibson memberi pengertian tentang cyberspace sebagai sekumpulan data, representasi grafik demi grafik dan hanya bias diakses oleh komputer (Nasrullah, 2016:18).

Perkembangan media tersebut, sebagaimana dikemukakan oleh Everett M. Rogers, dikenal ada empat era komunikasi yaitu: era tulis, era media cetak, era media telekomunikasi, dan era komunikasi interaktif (Bungin, 2009:111). Pada era komunikasi interaktif ini, ditandai dengan adanya diversifikasi teknologi informasi dengan bergabungnya telpon, radio, komputer, dan televisi menjadi satu dan menandai teknologi internet. 


\section{Media Sosial}

Terdapat empat era atau zaman dalam sejarah media dan masingmasing era berhubungan dengan mode komunikasi dominan pada era bersangkutan, McLuhan bersama Quentin Fiore (Morissan, 2013:488). Lebih lanjut, McLuhan menjelaskan tentang masing-masing era yaitu kesukuan (tribal); tulisan (literate); cetak (print); dan elektronik. Era kesukuan, indra pendengaran, penciuman, dan perasa merupakan indera yang lebih banyak digunakan oleh manusia, terutama indera pendengaran. Sementara pada era tulisan, orang menekankan pada indera penglihatan yang ditandai dengan diperkenalkannya huruf abjad (alphabet) dan karenanya mata menjadi indera yang dominan dalam berkomunikasi. Pada era cetak, penemuan mesin cetak memberikan tanda munculnya era cetak dalam peradaban manusia. Dan terakhir, era eletronika, kehidupan sebagian besar umat manusia sangat tergantung pada teknologi eletronik. Melalui media eletronik, memperluas persepsi orang melampaui batas batas tempat mereka berada, hal ini menunjukan peran media sosial menjadi sesuatu yang sangat dibutuhkan.

Zafarani (2014:1) berpendapat bahwa Informasi dikumpulkan,dan disebarkan oleh citizen journalists dan terus akan terus tersebar atau dikonsumsi oleh berbagai kalangan, yang akan memberikan feedback spontan. Dengan demikian perkembangan informasi sejalan dengan perkembangan media sebagaimana dinyatakan B. Ellison dan M. Boyd (2008:216) perkembangan pesat media sosial berlangsung sejak 2003 ketika bermunculan situs jejaring sosial. Pada saat ini, media sosial yang paling populer dan sering/ digunakan untuk saling berinteraksi dan berbagi informasi adalah Facebook, Twitter, Google+, Whatsapp, dan lain lain. Selain media sosial tersebut, di berbagai belahan dunia ada media sosial yang populer di negara tertentu, seperti Qzone, Tencent Weibo, dan Sina Weibo di Cina; Cyworld dan me2day di Korea Selatan; Orkut di Brasil, Vkontakte dan Odnoklassiniki di Rusia; dan Tuenti di Spanyol (Ibrahim \& Iriantara, 2017: 220).

M. Kaplan dan Haenlein (2010:62-64) membagi berbagi jenis media sosial kedalam 6 (enam) jenis, yaitu:

a. Collaborative Projects, yaitu suatu media sosial yang memungkinkan khalayak secara global untuk membuat atau merubah konten didalam website tersebut. Contoh media sosial paling populer yang masuk dalam kategori collaborative projects ini adalah wikipedia. Walaupun mungkin saja isi kontennya tidak benar, banyak pengguna internet yang tetap percaya dan menggunakannya.

b. Blogs, yaitu media sosial yang membantu penggunanya untuk berbagai opini, kegiatan sehari-hari, membuat review mengenai dalam format yang berbeda-beda, seperti teks, gambar, video, atau gabungan seluruh format. Contohcontoh media sosial berbentuk blogs paling terkenal adalah blogger, tumblr, dan wordpress. Berbeda dengan 
collaborative projects, media sosia ini biasanya hanya dikelola oleh satu orang tapi bisa saja terjadi sebuah interaksi dengan orang lain melalui kolom komentar.

c. Content Communities, yaitu media sosial yang memungkinkan penggunanya saling berbagi konten. Media sosial ini ada untuk berbagai jenis media yang berbeda, contohnya seperti BookCrossing yang dapat saling berbagi buku digital, Flickr untuk berbagi gambar, Youtube untuk berbagi video, dan Slideshare untuk membagikan file PowerPoint. Tetapi, jenis media sosial ini mempunyai resiko pelanggaran hak cipta paling besar.

d. Social Networking Sites atau Situs jejaring Sosial, jenis media sosial ini memungkinkan pengguna internet untuk membuat profil atau data pribadi dan menghubungkannya dengan pengguna lain. Situs jejaring sosial pada umumnya digunakan untuk mengunggah hal-hal yang bersifat pribadi, misalnya tulisan tentang kegiatan yang baru saja dilakukan pengunggah, temasuk gambar, video, berkas audio, dan blog. Situs jejaring sosial paling banyak digemari anak muda, dan juga digunakan perusahaan untuk mempromosikan mereknya.

e. Virtual Social Worlds, yaitu aplikasi yang mensimulasi kehidupan nyata dalam internet. Berbeda dengan Game Worlds, media ini memberi kesempatan penggunanya untuk membuat profil sesuai data diri penggunanya tanpa perlu membuat avatar. Penggunanya dapat berinteraksi dengan pengguna lainnya sama seperti dunia nyata, dengan cara saling berbagi ID atau Username. Media ini sangat membantu dalam menerapkan suatu strategi pemasaran atau penyampaian informasi secara interaktif serta menarik.

Dari 6 (enam) jenis media sosial, sebagaimana di atas jenis media sosial yang di kaji dalam tulisan ini adalah jejaring sosial Facebook.

\section{Facebook}

Facebook merupakan situs jaringan paling populer di kalangan mahasiswa dan karena memiliki format yang tetap memudahkan bagi para peneliti untuk membandingkan halaman pengguna. Dibuat pada tahun 2004, perkembangan platform ini begitu pesat sehingga pada tahun 2007 Facebook dilaporkan telah lebih dari 21 juta anggota terdaftar menghasilkan 1,6 miliar tampilan halaman setiap harinya.

Para pengguna biasa menghabiskan sekitar 20 menit setiap hari di situs ini, dan dua-pertiga dari pengguna log in paling tidak sekali sehari. Memanfaatkan keberhasilannya di kalangan mahasiswa, Facebook meluncurkan versi SMA pada awal September 2005. Pada tahun 2006, perusahaan memperkenalkan masyarakat untuk 
organisasi komersial; per November 2006, hampir 22.000 organisasi telah Facebook direktori. Pada tahun 2006, Facebook yang digunakan di Amerika Serikat lebih dari 2.000 perguruan tinggi dan ketujuh situs paling populer di World Wide Web yang berkaitan dengan jumlah tampilan halaman. Sebagian besar penelitian akademis yang ada di Facebook telah difokuskan pada presentasi identitas dan privasi keprihatinan. Melihat jumlah peserta memberikan Facebook informasi tentang diri mereka sendiri, yang relatif terbuka sifat informasi, dan kurangnya kendali pribadi disahkan oleh pengguna, Gross dan Acquisti menyatakan bahwa pengguna dapat menempatkan diri pada risiko baik offline (misalnya , menguntit) dan online (misalnya, mengidentifikasi pencurian). Facebook pun kini menjadi situs keempat yang paling sering dikunjungi di dunia. Mengapa Facebook mengejar MySpace, situs jaringan sosial terbesar pertama di dunia sebelum April 2008, Keadaan kemudian berubah, Facebook tidak lagi nomor dua sebagaimana ditulis di situs Techcrunch.

\section{Pilkada}

Pemilihan kepala daerah atau disingkat pilkada merupakan sarana yang disediakan bagi rakyat untuk menjalankan kedaulatannya. Hal ini sesuai dengan azas dalam Pembukaan UUD 1945. Pada dasarnya pilkada merupakan suatu Lembaga Demokrasi yang dipakai untuk memilih anggota-anggota perwakilan rakyat. Pilkada dilakukan secara langsung oleh penduduk daerah administratif setempat yang memenuhi syarat. Berdasarkan UU
No.32 Tahun 2004, peserta pilkada adalah calon yang sudah diusulkan oleh partai politik atau gabungan partai politik. Ketentuan ini lalu diubah pada UU No.12 Tahun 2008 yang menyatakan bahwa kandidat juga dapat berasal dari pasangan calon perseorangan yang didukung oleh sejumlah orang. Pada tahun 2018 ada 171 daerah baik setingkat propinsi, kabupaten atau kotamadya di Indonesia yang akan melaksanakan pemilihan kepala daerah. Rinciannya terdiri atas 115 kabupaten, 39 kotamadya, dan 17 provinsi yang mengikuti Pilkada serentak (http://nasional.sindonews.com).

Berdasarkan undang-undang tersebut telah terjadi perubahan system perpolitikan dalam pemilihan kepala daerah yang semula dipi lih oleh Dewan Perwakilan Rakyat Daerah (DPRD) kemudian dipilih langsung oleh masyarakat secara serentak. Pemilihan umum Bupati Donggala tahun 2018 merupakan pemilihan umum untuk memilih bupati dan wakil bupati periode 20182023. Pemilihan secara langsung ini merupakan pemilihan yang ketiga setelah pilkada 2008. Kekuatan partai politik dalam pilkada memang sangat dominan, hal ini tampak dari data pada tahun 2013 terdapat pilkada serentak di 269 daerah hanya terdapat 8 pasangan terpilih dari calon perseorangan Arya Fernandes, (jpnn.com 18/3/2016). Dengan dominannya eksistensi partai politik ini, tentunya dalam memenangkan paslon yang diusupnya akan menggunakan berbagai peluang termasuk pengguna Facebook. Pilkada tidak dapat lepas dari peran media, hal ini didasari oleh popularitas, hal itu sebagaimana 
Subiakto dan Ida (2012:194) yang menyatakan bahwa, kepentingan politik para bakal calon bupati/walikota dan gubernur terhadap media untuk kepentingan popularitas, karena semakin popular seseorang dilansir oleh media maka semakin punya peluang besar untuk terpilih.

Terdapat 3 fungsi media yang melekat dalam tugas mereka, yaitu memberi informasi, memberi pendidikan, dan menghibur masyarakat. Sebagai tugas media memberi informasi kepada masyarakat umum secara tepat waktu, bertanggung jawab sehingga informasi tersebut dapat dijadikan pedoman atau pengambil kebijakan yang disesuaikan dengan kebutuhan dari informasi tersebut; fungsi media dalam memberikan pendidikan terutama pada impact dari informasi tersebut bernuansa mendidik, artinya setelah mendapatkan informasi khalayak menjadi cerdas sehingga dapat mengambil keputusan yang tepat; pada aspek lain fungsi media juga menghibur masyarakat. Hal ini dimaksudkan adalah dengan adanya informasi, khalayak menjadi terhibur. Melalui peran media tersebut dapat membantu khalayaknya untuk membentuk pendapat tentang berbagai persoalan sehingga mereka dapat membuat keputusan sendiri tentang berbagai aspek kehidupan termasuk persoalan politik (pilkada). Peran media dalam pelaksaan pilkada di Indonesia memiliki peran cukup besar bukan saja tentang memberi suara, tetapi mendidik masyarakat. Sejalan dengan hal tersebut peran media menyebarkan opini public yang menghasilkan pendapat atau pandangan yang dominan, sementara individu dalam hal menyampaikan pandangannya akan bergantung pada pandangan yang dominan tersebut Noelle- Neumann (Subiakto dan Ida 2012).

\section{Pemilih Pemula}

2012 tentang Pemilihan Umum Anggota DPR, DPD dan DPRD Nomor 18, pemilih pemula adalah Warga Negara Indonesia yang telah genap berumur 17 (tujuh belas) tahun atau lebih atau sudah atau pernah kawin. Pemilih di Indonesia dibagi menjadi tiga kategori, yaitu: pertama pemilih rasional, yakni pemilih yang benar-benar memilih partai berdasarkan penilaian dan analisis mendalam; kedua, pemilih kritis emosional, yakni pemilih yang masih idealis dan tidak kenal kompromi; dan ketiga, pemilih pemula, yakni pemilih yang baru pertama kali memilih karena usia mereka baru memasuki usia sebagai pemilih.

Salah satu kategori pemilih yang mempunyai pengaruh besar terhadap kehidupan demokrasi di masa mendatang adalah pemilih pemula, selain jumlahnya yang akan terus bertambah, potensi daya kritis mereka dapat menentukan sebuah hasil pemilihan. Pemilih pemula adalah pemilih yang baru pertama kali akan menggunakan hak pilihnya, terdiri dari masyarakat yang telah memenuhi syarat untuk memilih.

Pemilih pemula juga dijelaskan pada Modul I Komisi Pemilihan Umum (2013 kategori pemilih pemula adalah warga negara yang baru pertama kali akan menggunakan hak pilihnya didalam kegiatan pemilihan umum (pemilu). Mereka biasa berasal dari Warga Negara 
Indonesia (WNI) yang genap berusia 17 tahun atau belum berusia 17 tahun tetapi sudah menikah (Wardhani:2018). Pemilih pemula ini merupakan generasi muda yang memiliki sifat dan karakter, latar belakang, perjalanan dan tantangan yang berbeda. Sebagian besar diantara mereka berasal dari kalangan pelajar dengan status ekonomi yang berbeda dan saat ini telah bersentuhan dengan kemajuan teknologi berupa gadget yang dapat mengakses berbagai informasi di media sosial.

Selain itu pemilih pemula sangat terbuka dalam mempelajari atau menerima hal-hal baru. Hal ini menunjukkan telah terjadi perubahan antara generasi atau pemilih pemula saat ini dengan generasi sebelumnya. Sebagaimana K.Garna, (1996:184) bahwa masyarakat itu perkembang melalui suatu rangkaian tahapan yang evolusionistik. Perbedaan antara generasi saat ini dengan generasi lalu, terutama disebabkan oleh penemuan teknologi terutama handphone. Penemuan handphone sebagai sebuah loncatan kemajuan teknologi, sudah dapat diterima khususnya pemilih pemula yang dapat diamati dengan mudahnya mengaplikasikan handphone untuk digunakan mengakses berbagai informasi di media sosial. Hadirnya informasi melalui internet dianggap cocok dengan gaya hidup anak muda (pemilih pemula) hari ini dan dinilai sangat efektif untuk dimanfaatkan oleh kelompok kepentingan yang menyebarkan informasi sesuai dengan kepentingan kelompok tersebut. Oleh karena itu generasi muda termasuk pemilih pemula harus didorong untuk memiliki kapasitas dan skill cerdas media agar mampu menyaring, memilah, dan memilih secara selektif berbagai informasi dan pengetahuan yang bertebaran di dunia maya. (Agus SB, 2016:24).

\section{Persepsi}

Jalaluddin Rakhmat (2011: 50) menyatakan, bahwa persepsi adalah pengalaman tentang objek, peristiwa, atau hubungan-hubungan yang diperoleh dengan menyimpulkan informasi dan menafsirkan pesan. Dalam Kamus Lengkap Psikologi oleh Chaplin (2014: 358), dinyatakan, bahwa persepsi merupakan proses mengetahui atau mengenali objek dan kejadian objektif dengan bantuan indera. Sejalan dengan hal tersebut, Mulyana (2002:168) yang menyatakan bahwa persepsi meliputi pengindraan (sensasi) melalui alatalat indra kita (yakni indra peraba, indra penglihat, indra pencium, indra pencium, indra pengecap dan indra pendengar), atensi, dan interpretasi. Oleh karena itu dapat disimpulkan bahwa, setiap indra mempunyai andil bagi berlangsungnya komunikasi. Sejalan dengan hal tersebut dikutip dari Liliweri (2011:158), persepsi terdiri dari 5 (lima) jenis, yaitu:

a. Persepsi Diri, yaitu bagaimana individu menerima diri sendiri dan bagaimana dirinya berpikir tentang orang lain dan menerimanya. Persepsi diri dapat juga disebabkan oleh pengalaman masa lalu atau informasi yang ia telah terima.

b. Persepsi Lingkungan, yaitu persepsi yang dibentuk oleh informasi sesuai dari mana informasi tersebut diterima. Lingkungan disekeliling kita dapat mempengaruhi dan membentuk persepsi terhadap 
informasi.

c. Persepsi yang Dipelajari, yaitu persepsi yang terbentuk saat individu mempelajari sesuatu dari lingkungan sekitar, misalnya kebiasaan sahabat yang telah kita pelajari akan membentuk pikiran, ide, atau gagasan dan keyakinan kita mengenai sahabat tersebut.

d. Persepsi Fisik, yaitu persepsi yang dibentuk melalui indra dan diproyeksikan pada bagian tertentu dalam otak individu, sehingga dapat mengamati objek tersebut.

e. Persepsi Budaya, yaitu persepsi yang dibentuk sesuai dengan identitas atau dimana individu tersebut dibesarkan. Persepsi budaya sangat bervariasi, dan kadang-kadang dapat menimbulkan stereotip.

Selain jenis-jenis persepsi, sebagaimana dijelaskan Sarwono (2000:43-44), bahwa terdapat beberapa faktor terjadinya persepsi, yaitu:

a. Perhatian, biasanya tidak menangkap seluruh rangsang yang ada disekitar kita sekaligus, tetapi memfokuskan perhatian pada satu atau dua objek saja. Perbedaan fokus perhatian antara satu orang dengan orang yang lain akan menyebabkan perbedaan persepsi.

b. Set, adalah harapan seseorang akan rangsang yang akan timbul. Perbedaan set akan menyebabkan adanya perbedaan persepsi.

c. Kebutuhan,yaitu ketika masing- masing individu mempunyai kebutuhan yang berbeda, baik kebutuhan sesaat maupun kebutuhan menetap. Kebutuhan itulah yang mempengaruhi persepsi.

d. Sistem Nilai, sistem nilai yang berlaku dalam masyarakat akan berpengaruh pula terhadap persepsi.

e. Ciri Kepribadian, yaitu pola kepribadian yang dimiliki oleh individu juga akan menghasilkan persepsi yang berbeda.

Selain jenis persepsi, faktorfaktor persepsi juga terdapat tahaptahap persepsi yang merupakan proses dimana individu menjadi lebih sadar tentang objek, peristiwa dan informasi dalam dunia sekeliling. Proses ini dituliskan oleh Liliweri (2011: 157- 158) terjadi dalam 3 (tiga) tahapan utama, yaitu;(1) Individu memperhatikan dan membuat seleksi; (2) Individu mengorganisasikan objek yang ditangkap indra; (3) Individu membuat interpretasi. Sementara, dituliskan oleh Liliweri tahapan menurut pemerhati psikologi komunikasi mengikuti 5 (lima) tahapan utama, yaitu:

a. Stimulation, Tahap pertama ini, individu menerima rangsangan dan indra akan menangkap makna dari rangsangan tersebut.

b. Organization, Rangsangan tersebut kemudian diorganisasikan atau dikelompokkan berdasarkan tatanan tertentu;

c. Interpretation-evaluation, Pada tahap ini individu membuat interpretasi dan evaluasi terhadap stimulus 
berdasarkan informasi apa yang dia terima

d. Memory, Rangsangan yang sudah dikelompokkan akan terekam dalam memori.

e. Recall, Semua yang telah terekam dikeluarkan, itulah persepsi.

Sejalan dengan Irwanto (2002:71), yang menyatakan bahwa setelah individu melakukan interaksi dengan obyek-obyek yang dipersepsikan maka hasil persepsi dapat dibagi menjadi dua yaitu:

a. Persepsi positif, yaitu persepsi yang menggambarkan segala pengetahuan dengan upayanya.

b. Persepsi negatif, yaitu persepsi yang menggambarkan segala pengetahuan dengan obyek yang di persepsi. Hal itu akan di teruskan dengan kepasifan atau menolak dan menentang terhadap obyek yang dipersepsikan.

Dengan demikian dapat di katakan bahwa persepsi itu baik yang positif maupun yang negatif akan selalu mempengaruhi diri seseorang dalam melakukan suatu tindakan, munculnya suatu persepsi positif ataupun persepsi negatif semua itu tergantung pada bagaimana cara individu menggambarkan segala pengetahuannya tentang suatu obyek yang di persepsi. David Crech dan Richard S Crutchfild (Rakhmat, 2011) menjelaskan bahwa persepsi dipengaruhi oleh factor fungsional dan faktor struktural. Persepsi bersifat selektif secara fungsional menunjukan bahwa objek-objek yang mendapat tekanan dalam persepsi biasanya objek-objek yang memenuhi tujuan individu yang melakukan persepsi. Sedangkan faktor struktural berasal dari sifat stimulus, fisik dan efek-efek saraf yang ditimbulkannya pada system saraf individu.

Pakar lain melihat persepsi dipengaruhi oleh situasional dan personal. Situasional terkadang disebut determinan, perhatian yang bersifat eksternal atau penarik perhatian (attention giver), stimulus diperhatikan karena memiliki sifatsifat menonjol antara lain gerakan, intensitas stimulus, kebaruan dan perulangan. Sedangkan faktor personal berasal dari kebutuhan, pengalaman masa lalu, dan hal hal lain. Dengan kata lain yang menentukan persepsi bukan saja jenis atau stimulus tetapi karakteristik orang yang memberikan respon pada stimulus itu.

\section{Metode Penelitian}

Tipe penelitian yang digunakan adalah deskriptif kuantitatif. Seperti yang dinyatakan John Creswell dalam Silalahi Ulber (2009:76-77) bahwa, penelitian kuantitatif adalah tipe penelitian yang dapat dikonstruksi sebagai strategi penelitian yang menekankan kuantifikasi dalam pengumpulan dan analisis data dengan pendekatan deduktif untuk hubungan antara teori dengan penelitian, dengan menempatkan pengujian teori (testing of theory). Oleh karena itu, penelitian kuantitatif merupakan sebuah penyelidikan tentang masalah sosial berdasarkan pada pengujian sebuah teori yang terdiri dari variabel-variabel, diukur dengan angka dan dianalisis dengan prosedur statistik untuk menentukan apakah generalisasi prediktif teori tersebut benar. 


\section{Hasil Dan Pembahasan}

Persepsi Berdasarkan Perhatian Persepsi adalah merupakan suatu proses yang dimulai dari penglihatan hingga terbentuk tanggapan yang terjadi dalam diri pribadi sehingga sadar akan segala sesuatu dalam lingkungannya melalui indera yang dimilikinya. Proses menginterpretasikan rangsangan ini biasanya dipengaruhi pula oleh pengalaman dan proses belajar individu. Persepsi dapat dikatakan sebagai suatu pengalaman objek, peristiwa, atau hubungan-hubungan yang diperoleh dengan menyimpulkan informasi dan menafsirkan pesan.

Setiap individu manusia memiliki perbedaan dalam hal sifat, pengalaman, lingkungan, serta golongan sosial yang meliputi tempat tinggal, pendidikan, status sosial, jenis kelamin, usia, agama, dan suku bangsa. Karakteristik tersebut tentunya juga memunculkan adanya perbedaan kebutuhan terhadap media maupun respon terhadap isinya. Kebutuhan individu memperoleh informasi karena keingintahuan mengenai berbagai peristiwa dan kondisi yang berkaitan dengan lingkungan masyarakat sekitar, keadaan dunia, mencari bimbingan terkait dengan berbagai masalah, pendapat, dan menambah pengetahuan.

Motif identitas personal terkait sekali dengan nilai-nilai individu yang dapat diperoleh melalui media ataupun nilai tambah sebagai pembaca/khalayak media. Integritas dan interaksi sosial terkait dengan motivasi untuk menemukan materi diskusi dalam interaksi sosial, menjalankan peran sosial, dekat dan dihormati orang lain. Penggunaan media sebagai hiburan seperti melepaskan diri dari permasalahan, mengisi waktu luang dan bersantai, mendapatkan kesenangan, dan menyalurkan emosi.

Media sosial merupakan salah satu media yang di pakai pada masa ini dan kini menjadi saluran informasi dalam berbagai bidang. Bidang pendidikan, sosial, ekonomi dan juga politik contohnya promosi produk, transaksi jual beli barang online, pengumuman hasil tes ujian jugasosialisasi politik pada pemilihan umum. Hal ini didukung dengan teknologi yang semakin berkembang sehingga mempermudah pengunaan internet yang menjadi akses masuk media sosial. Ini menunjukan perubahan pengunaan media dari media lama (media elektronik dancetak) kepada media baru ( media online). Dalam bidang politik sendiri media sosial yang merupakan bagian media online atau media baru, mulai di gunakan sebagai media sosialisasi politik karena biaya pengunaan yang murah dan aksesnya yang tidak terbatas.

Demikian halnya persepsi dalam hal Pemilihan Kepala Daerah (Pilkada) di Kabupaten Donggala, dimana dalam penelitian ini terfokus pada persepsi pemilih pemula. Pemilih yang sering terpapar pesanpesan komunikasi melalui media sosial adalahpemilih pemula yang rentang umurnya 17-21 tahun, karena pemilih pada umur ini sangat aktif menggunakan media sosial sebagai sumber informasi utama dalam kehidupan sehari hari.

Pemilih pemula merupakan golongan masyarakat yang berusia 17 hingga 21 tahun dan tercatat pada saat berpartisipasi dalam pemilihan umum. 
Pemilih pemula merupakan target dari partai politik karena dianggap belum memiliki pengalaman dan pengetahuan tentang pemilihan umum. Pemilih pemula dianggap masih berada pada sikap dan pilihan politik yang belum jelas. Sikap politik yang dimiliki pemilih pemula dapat diartikan sebagai suatu kesiapan bertindak, berper sepsi untuk merespon bagaimana pemilih pemula berpartisipasi dalam pemilihan umum. Sikap politik dapat diungkapkan dalam berbagai bentuk. Adapun kebanyakan pemilih pemula memilih partai pilihan orangtuanya. Orang dewasa kendati dalam memilih memutuskan sendiri pilihannya, namun pilihan itu ternyata ada kesesuaian dengan pilihan anggota keluarganya. Untuk mengetahui persepsi pemilih pemula tentang pemanfaatan media sosial Facebook pada Pemilihan Kepala Daerah (Pilkada) 2018 di Kabupaten Donggala dapat dilihat dari uraian pembahasan berikut ini.

Dari hasil kuesioner tentang pengetahuan responden dalam hal ini pemilih pemula adalah bahwa Pemilihan Kepala Daerah (Pilkada) 2018 di Kabupaten Donggala rata-rata merupakan pertama kalinya mendapat kesempatan memilih. Dan tanggapan responden terhadap pemanfaatan media sosial dalam Pemilihan Kepala Daerah (Pilkada) cukup memberikan pengaruh dalam membangun persepsi pemilih pemula. Akan tetapi pada kenyataannya pilihan tersebut lebih banyak dipengaruhi pilihan keluarga karena dinilai belum matang dalam menentukan pilihan tersebut.

Adapun persepsi tentang pemanfaatan media sosial dalam hal ini Facebook, sebagaimana pilihan yang paling dominan digunakan pemilih pemula, maka dapat diuraikan dalam pembahasan berikut ini; Persepsi Berdasarkan Perhatian, Perhatian yaitu kemampuan untuk menangkap rangsangan yang datang dari luar dirinya, khususnya terhadap rangsangan menarik dirinya. Perhatian, biasanya tidak menangkap seluruh rangsang yang ada disekitar kita sekaligus, tetapi memfokuskan perhatian pada satu atau dua objek saja. Perbedaan fokus perhatian antara satu orang dengan orang yang lain akan menyebabkan perbedaan persepsi. Dalam menyadari atau belum mengadakan persepsi diperlukan adanya perhatian, yaitu merupakan langkah utama sebagai suatu persiapan dalam rangka mengadakan persepsi. Perhatian merupakan pemusatan atau konsentrasi dari seluruh aktivitas individu yang ditujukan kepada sesuatu sekumpulan objek.

Dari hasil penelitan, sesuai yang dikaitkan dengan teori persepsi sebagaimana pandangan Sarwono (2004:43-44) menunjukkan bahwa: 1). terdapat 58 responden yang menyatakan perhatian pada berita tentang pilkada melalui Facebook; 2). terdapat 55 responden yang menyatakan mengikuti perkembangan pada pilkada melalui media sosial Facebook; 3). Facebook dalam pilkada Donggala mampu merangsang simpatik pemilih pemula yang ditandai dengan pilihan responden sebanyak 54 orang; 4). kesesuaian informasi dan harapan dianggap tidak sesuai bagi responden dengan jumlah responden sebanyak 42 orang $(59,15 \%) ; 5)$. terdapat 46 responden $(64,79 \%)$ yang menyatakan bahwa informasi pilkada tidak dapat 
mempengaruhi pola pikir pemilih pemula; 6). informasi melalui Facebook tentang pilkada menjadi sesuatu yang tidak butuhkan hal ini dapat dilihat dari pilihan responden sebanyak 34 orang atau $(47,89 \%) ; 7)$. terdapat 46 responden yang menyatakan bahwa media sosial Facebook, baik untuk menyampaikan informasi tentang kandidat; 8). 42 responden $(59,15 \%)$ menilai bahwa media sosial Facebook dianggap tidak mampu mempengaruhi pilihan pada pemilih pemula; 9). terdapat 53 responden yang menyatakan sistem nilai penting dalam media sosial Facebook dalam pilkada; 10). terdapat 51 responden $(71,83)$ menyatakan bahwa media sosial Facebook pada pilkada tidak bertentangan dengan sistem nilai yang berlaku dalam masyarakat; 11). terdapat 57 responden yang menyatakan bahwa informasi yang didapatkan dalam media sosial Facebook terdapat kesesuaian dengan kepribadian; 12). 34 responden yang menyatakan terdapat berbedaan persepsi diantara pemilih pemula dalam menentukan pilihan pada pilkada Kabupaten Donggala.

Selain pandangan Sarwono (2000) tentang jenis persepsi, juga digunakan pandangan Liliweri (2011: 157- 158), yaitu terdapat tahapan dalam persepsi, yaitu: (1) Individu memperhatikan dan membuat seleksi, umumnya responden dalam menentukan pilkada mengatakan bahwa informasi lewat Facebook tidak mempengaruhi pilihan mereka, ini menunjukan mereka sangat selektif terhadap informasi melalui media tersebut; (2) Individu mengorganisasikan objek yang ditangkap indra, hal ini dapat dilihat bahwa individu mengorganisir setiap informasi tentang pilkada melalui Facebook bukan merupakan kebutuhan, dan (3) Individu membuat interpretasi terhadap informasi sangat dimungkinkan karena informasi tentang pilkada melalui Facebook tidak berpengaruh terhadap pilihan mereka.

Dalam persepsi sebagaimana Irwanto (2002: 71), yang menyatakan bahwa setelah individu melakukan interaksi dengan obyek- obyek yang di persepsikan maka hasil persepsi dapat dibagi menjadi dua yaitu: (a) Persepsi positif, dan (b) persepsi negatif. Hal ini sangat tergantung pada bagaimana cara individu menggambarkan segala pengetahuannya tentang objek yang dipersepsi. Berdasarkan hasil lapangan terhadap 71 responden sebagaimana pada tabel 4.3.a terdapat 42 orang atau $(59,15 \%)$ yang menyatakan bahwa kesusaian harapan atau informasi sangat tidak sesuai. Demikian pula pada tabel 4.3.b bahwa peran media sosial Facebook tidak membantu memberikan informasi sejumlah 45 orang atau $(63,38 \%)$ dari data ini memberikan penjelasan bahwa persepsi responden terhadap informasi melalui Facebook cenderung negatif.

\section{Kesimpulan}

Berdasarkan hasil penelitian dan pembahasan tentang "Persepsi Pemilih Pemula Tentang Pemanfaatan Media Sosial Facebook pada Pilkada 2018 di Kabupaten Donggala" maka dapat ditarik kesimpulan sebgai berikut:

1. Perhatian responden terhadap berita pilkada melalui facebook sejumlah 58 
responden hal in menunjukkan bahwa responden memiliki perhatian. Termasuk didalamnya mengikuti perkembangan dan mampu merangsang simpatik pemilih pemula;

2. Set, terdapat 42 responden $(59,15 \%)$ menyatakan bahwa kesesuaian informasi dan harapan pada informasi melalui facebook dianggap tidak sesuai.

3. Kebutuhan, informasi melalui facebook tentang pilkada menjadi sesuatu yang bukan kebutuhan hal ini dapat dilihat dari pilihan responden sebanyak 34 orang $(47,89 \%)$;

4. Sistem Nilai, terdapat 53 responden yang menyatakan bahwa sistem nilai itu penting dalam media sosial facebook dan tidak bertentangan dengan nilai yang berlaku dalam masyarakat.

5. Kepribadian, terdapat 57 responden yang menyatakan bahwa informasi yang didapatkan dalam media sosial facebook terdapat kesesuaian dengan kepribadian dan terdapat perbedaan persepsi diantara pemilih pemula dalam menentukan pilihannya.

\section{Referensi}

Agus, SB. 2016. Deradikalisasi Dunia Maya Mencegah Simbiosis Terorisme dan Media. Jakarta: Daulat Press Jakarta.

Baran, Stanley J. 2004. Theory of Media Literacy: A Cognitive Approach. London: Sage. Bungin,
Burhan. 2014. Sosiologi Komunikasi.

Jakarta: Kencana Prenada

Media Group. Chaplin, J.P. 2014.

Kamus Lengkap Psikologi. Jakarta: PT RajaGrafindo Persada.

El Ishaq, Ropingi. 2017. Public

Relations Teori dan Praktik. Malang:

Intrans Publishing.

Garna, Judistira K. 1996. Ilmu-ilmu

Sosial Dasar Konsep, Posisi.

Bandung: $\quad$ Program Pasca Sarjana

Universitas Padjajaran.

Ibrahim, Subandi dan YosalIriantara. 2017. Komunikasi Yang Mengubah

Dunia; $\quad$ Revolusi Dari Aksara. Bandung: Simbiosa Rekatama Media.

Irwanto. 2002. Psikologi Umum. Jakarta: PT. Prehallindo.

Liliweri, Alo. 2011. Komunikasi

Serba Ada Serba Makna. Jakarta:

Kencana.

M. Kaplan, Andreas dan Michael Haenlein. 2010. Users of the World, Unite! The Challenges and Opportunities of Social Media. Kelley School of Business, Indiana

University.

Mandiberg, Michael. 2012. The Social Media Reader. London: New York University Press. Morissan. 2013. Teori Komunikasi: Individu Hingga Massa. Jakarta:

Kencana.

Mulyana, Deddy. 2002. Ilmu

Komunikasi Suatu Pengantar. Bandung: PT. Remaja Rosdakarya Offset. 
Rakhmat, Jalaluddin. 2011. Psikologi Komunikasi. Bandung: PT. Remaja

Rosdakarya Offset. Subiakto, Henry dan Ida, Rachmah. 2012. Komunikasi politik, media, dan demokrasi.

Jakarta: Kencana.

J. Severin, Werner dan Jr W.

Tankard. 2011. Teori Komunikasi:

Sejarah, Metode, \& Terapan di Dalam Media Massa, Edisi Ke-5.

Jakarta: Kencana.

Kriyantono, Rachmat. 2014. Teknik

Riset Komunikasi. Jakarta: Kencana

Prenadamedia Group. Nasrullah, Rulli. 2016. Teori dan Riset: Media Siber (cybermedia). Jakarta:

Kencana.

Riduwan. 2004. Metode dan Teknik Menyusun Tesis. Bandung: Alfabeta.

-. 2013. Skala Pengukuran Variabelvariebel Penelitian. Bandung:

Alfabeta.

Sarwono, WirawanSarlito. 2000.

Pengantar Umum Psikologi. Jakarta:

Bulan Bintang.

Silalahi, Ulber. 2009. Metode

Penelitian Sosial. Bandung: PT.

Refika Aditama.

Sugiyono. 2005. Metode Penelitian

Bisnis. Bandung: Alfabeta.

-. 2010. Metode Penelitian

Pendidikan Pendekatan Kuantitatif, kualitatif, dan R\&D. Bandung:

Alfabeta.
Auvinen, Ari-Matti. Social MediaThe New Power of Political Influence.

B. Ellison, Nicole dan Danah M. Boyd. 2008. Social Network Sites:

Definition, History, and

Scholarship.

Habermas, Jurgen. 2006.

Communication Theory.

Lalolo K.P. dan Zainal Munawaroh. 2018. Partisipasi Politik Pemilih

Pemula Dalam Bingkai

Jejaring Sosial di Media Sosial.

Universitas Swiss German.

Wardhani, Primandha Sukma Nur. 2018. Partisipasi Politik Pemilih

Pemula dalam Pemilihan

Umum.

Zafarani, Reza et al. 2014. Social Media Minning. America: University of Cambridege 